\title{
Molecular genetic diversity in populations of the stingless bee Plebeia remota: A case study
}

\author{
Flávio de Oliveira Francisco, Leandro Rodrigues Santiago and Maria Cristina Arias \\ Departamento de Genética e Biologia Evolutiva, Instituto de Biociências, Universidade de São Paulo, \\ São Paulo, SP, Brazil.
}

\begin{abstract}
Genetic diversity is a major component of the biological diversity of an ecosystem. The survival of a population may be seriously threatened if its genetic diversity values are low. In this work, we measured the genetic diversity of the stingless bee Plebeia remota based on molecular data obtained by analyzing 15 microsatellite loci and sequencing two mitochondrial genes. Population structure and genetic diversity differed depending on the molecular marker analyzed: microsatellites showed low population structure and moderate to high genetic diversity, while mitochondrial DNA (mtDNA) showed high population structure and low diversity in three populations. Queen philopatry and male dispersal behavior are discussed as the main reasons for these findings.
\end{abstract}

Keywords: mtDNA, Meliponini, microsatellites, philopatry, population genetics.

Received: August 17, 2012; Accepted: November 9, 2012.

Most of the Brazilian tropical flora is pollinated by bees, especially by those belonging to the tribe Meliponini (stingless bees) (Kerr et al., 1996; Nogueira-Neto, 1997). The increase in habitat loss can lead to severe consequences for bee populations and species diversity (Foley et al., 2005; Brown and Paxton, 2009). Studies focusing on Meliponini general biology, including genetic diversity, are still scarce in the literature. Genetic data are essential for a better understanding of macro- and micro-evolutionary processes and patterns in organisms, and provide support for conservation and managing programs (Moritz, 2002; Frankham et al., 2004).

Recent studies have indicated a low genetic diversity in feral populations of Brazilian stingless bees (Costa et al., 2005; Arias et al., 2006; Tavares et al., 2007; Borges et al., 2010; Brito and Arias, 2010; Francisco and Arias, 2010). This low genetic diversity may have negative consequences for the long-term population survival rate and raises important questions related to conservation programs for the Meliponini.

An adequate understanding of how genetic diversity is distributed and maintained among stingless bee populations requires a consideration of behavioral components such as philopatry. Philopatry may restrict individual dispersion, leading to inbreeding, which consequently reduces heterozygosity; philopatry also increases the effects of genetic drift due to population subdivision and isolation.

Send correspondence to Maria Cristina Arias. Rua do Matão 277, sala 320, Cidade Universitária, 05508-090 São Paulo, SP, Brazil. E-mail: mcarias@ib.usp.br.
However, studies in a variety of organisms have shown that if one gender is philopatric then the other one normally mediates gene flow through dispersion (Whitehead, 1998; Nyakaana and Arctander, 1999; Kappeler et al., 2002; Apio et al., 2010). This behavioral mechanism minimizes the negative effects of philopatry.

It has already been demonstrated in some stingless bee species that the queen is philopatric (Nogueira-Neto, 1954; Engels and Imperatriz-Fonseca, 1990) and males are the dispersing sex (Carvalho-Zilse and Kerr, 2004; Cameron et al., 2004). Despite this dispersal by males, studies based on allozyme analysis (Tavares et al., 2007; Costa et al., 2005), RAPD (Tavares et al., 2007), mtDNA RFLP (Brito and Arias, 2010; Francisco and Arias, 2010) and microsatellites (Francisco et al., 2006; Tavares et al., 2007; Carvalho-Zilse et al., 2009; Borges et al., 2010) have revealed a low genetic diversity in Brazilian stingless bee populations.

The stingless bee Plebeia remota occurs in Bolivia and southeastern and southern Brazil (Camargo and Pedro, 2012). This species generally builds its nests in tree cavities, with colonies of up to 5,000 bees (van Benthem et al., 1995); the workers are small ( $\sim .5 \mathrm{~cm}$ in length) (Hilário et al., 2007). In a previous investigation, Francisco and Arias (2010) described low intrapopulation mitochondrial polymorphism for this species. In the present work, we reanalyzed most of those samples to measure nuclear genetic diversity based on the amplification of microsatellite loci with specific primers and also by sequencing two mitochondrial genes. 
One worker bee from each of 65 nests was analyzed for nuclear and mitochondrial loci. The samples originated from four localities (referred to from here on as "populations"): Cunha in São Paulo state $(\mathrm{n}=13)$, Curitiba $(\mathrm{n}=6)$ and Prudentópolis $(\mathrm{n}=34)$ in Paraná state and Blumenau $(\mathrm{n}=12)$ in Santa Catarina state (Figure 1). Total DNA was extracted using Chelex ${ }^{\circledR} 100$ (Bio-Rad) according to a protocol described by Walsh et al. (1991). All individuals were genotyped for 15 microsatellite loci (Francisco et al., 2011): Prem03, Prem07, Prem57, Prem58, Prem70, Prem75a, Prem78, Prem79, Prem81a, Prem82, Prem83, Prem84, Prem87, Prem93 and Prem94. Microsatellite amplification and visualization were done as described by Francisco et al. (2011). Allelic richness (A), observed and expected heterozygosities ( $H_{O}$ and $H_{E}$, respectively) from Hardy-Weinberg proportions, percentage of polymorphic loci and allele frequencies were calculated for each population using Genalex v.6.41 (Peakall and Smouse, 2006). Due to differences in sample size, rarefaction was applied to allelic richness $(A r)$ by using the program HP-Rare 1.0 (Kalinowski, 2005). Log likelihood ratio statistics for linkage disequilibrium were computed using Genepop v.4.1.4 (Rousset, 2008). The Bonferroni correction (Rice, 1989) was applied when multiple comparisons were done. Population structure was analyzed with the program Structure v.2.3.3 (Pritchard et al., 2000). The program was set up for 500,000 Markov chain Monte Carlo repetitions after an initial burn-in of 20,000 repetitions. The number of structured populations $(\mathrm{K})$ was estimated based on 10 replications for each K (from 1 to 4 ). The estimate of the best $\mathrm{K}$ was calcu- lated as described by Evanno et al. (2005) using Structure Harvester v.0.6.92 (Earl and VonHoldt, 2012). The program Clumpp v.1.1.2 (Jakobsson and Rosenberg, 2007) was used to align the 10 repetitions of the best $\mathrm{K}$. The program Distruct v.1.1 (Rosenberg, 2004) was used to graphically display the results produced by Clumpp. Population structure was also analyzed using the $D_{\text {est }}$ estimator (Jost, 2008) which was calculated for each population pair by the program SMOGD v.1.2.5 (Crawford, 2010).

Two mitochondrial genes, cytochrome c oxidase subunit I (COI) and cytochrome b $(C y t b)$, were partially amplified by using the primers mtD06 + mtD09 (Simon et al., 1994) and mtD26 (Simon et al., 1994) + AMB16 (Arias et al., 2008), respectively. PCR assays were done with $1 \mu \mathrm{L}$ of DNA, 1x PCR buffer, $200 \mu \mathrm{M}$ of each dNTP, $3 \mathrm{mM}$ of $\mathrm{MgCl}_{2}, 0.8 \mu \mathrm{M}$ of each primer, $1 \mathrm{M}$ of betaine anhydrous (USB Corporation) and $1 \mathrm{U}$ of Taq DNA polymerase (Invitrogen) in a final volume of $10 \mu \mathrm{L}$. The amplification conditions consisted of an initial denaturation at $94{ }^{\circ} \mathrm{C}$ for $5 \mathrm{~min}$, followed by 35 cycles of denaturation at $94{ }^{\circ} \mathrm{C}$ for $60 \mathrm{~s}$, annealing at $42{ }^{\circ} \mathrm{C}$ for $60 \mathrm{~s}$ and elongation at $64^{\circ} \mathrm{C}$ for $80 \mathrm{~s}$, and a final elongation step at $64^{\circ} \mathrm{C}$ for $10 \mathrm{~min}$. PCR products ( $2 \mu \mathrm{L}$ aliquots) were analyzed by electrophoresis in $0.8 \%$ agarose gels stained with GelRed (Biotium) and visualized under UV light. About 100-200 ng of each product was purified with $0.5 \mu \mathrm{L}$ of ExoSAP-IT(USB Corporation) and used for sequencing reactions according to the manufacturer's recommended protocols (BigDye Terminator v.3.1 Cycle sequencing kit, Applied Biosystems). The sam-

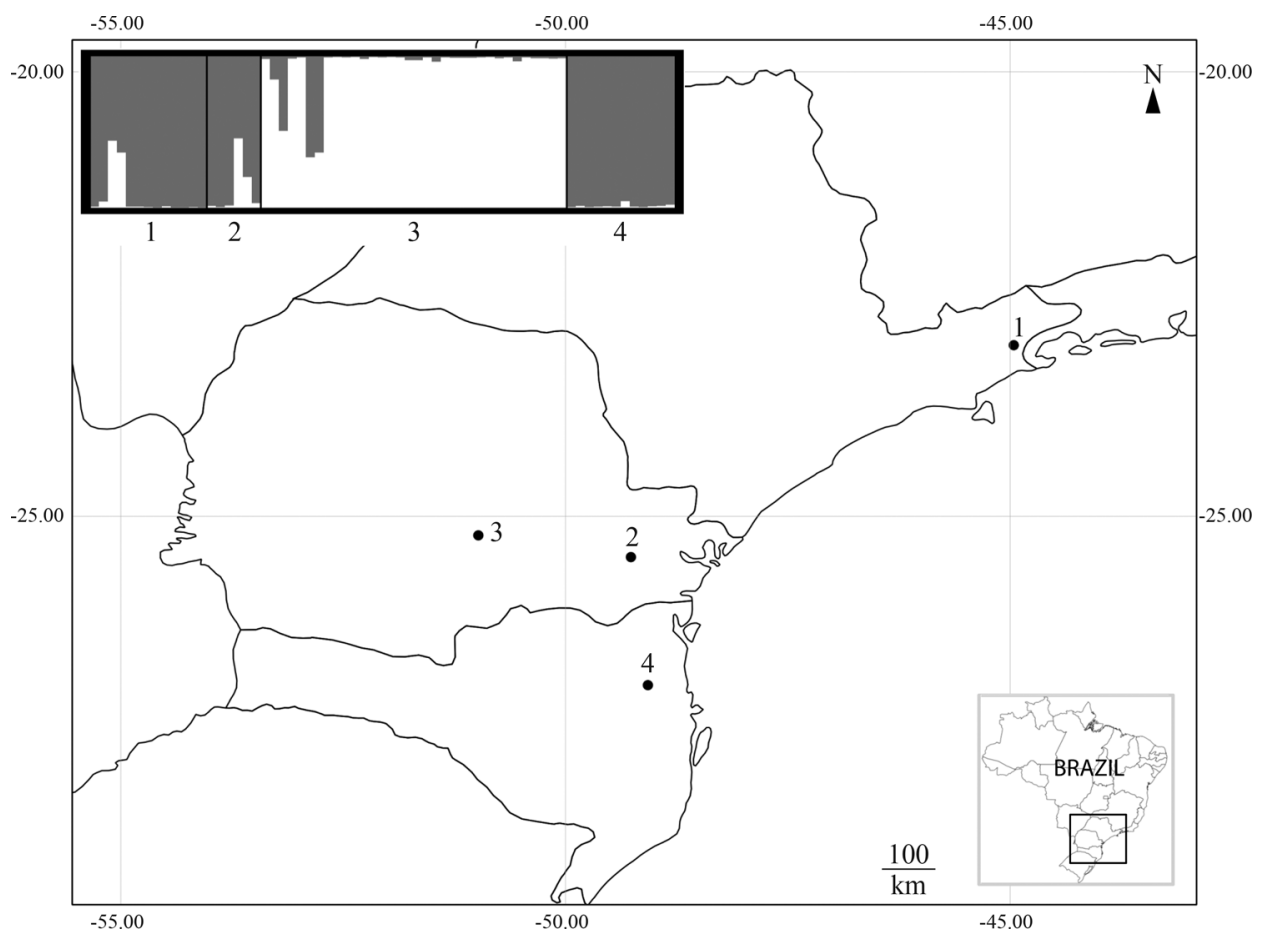

Figure 1 - Geographic location of Plebeia remota populations and graphic display of the Structure results. 1: Cunha $(\mathrm{n}=13), 2:$ Curitiba $(\mathrm{n}=6), 3$ : Prudentópolis $(\mathrm{n}=34)$ and 4: Blumenau $(\mathrm{n}=12)$. 
ples were analyzed in an automatic sequencer ABI PRISM 3100 Genetic Analyzer (Applied Biosystems). DNA sequences were edited using the Geneious v.5.1.6 software package (Drummond et al., 2010). The alignment was done using the algorithm Muscle (Edgar, 2004) from Geneious, with a maximum number of eight iterations. DnaSP v.5.10.01 software (Librado and Rozas, 2009) was used to identify individual haplotypes and their frequencies. A haplotype network was generated with the software Network v.4.6.1.0. Exact tests between pairs of populations were done using Arlequin v.3.5.1.3 (Excoffier and Lischer, 2010).

All microsatellite loci analyzed were polymorphic. The allele frequencies for each locus and for each population are included in the Supplementary material to this paper (Table S1). The intrapopulation genetic diversity indices ranged from moderate to high (Table 1). No significant linkage disequilibrium was detected after Bonferroni correction for each pair of loci tested. Population structure results divided the four populations into two clusters: [Cunha-Curitiba-Blumenau] and [Prudentópolis] (Figure 1 , Table $\mathrm{S} 2$ ).

A total of $794 \mathrm{bp}$ (415 from COI and 379 bp from $C y t b$ ) was obtained for all individuals (GenBank accession numbers JQ517144-JQ517273). Ten haplotypes were identified, most of which were exclusive to a specific population, except for one (h04) (Table 2). Table 2 also shows the haplotype and nucleotide diversity indices; they were not correlated to sample size. Figure 2 shows the network built to represent the associations between haplotypes and the genetic differentiation among populations. The maximum number of nucleotide differences between two haplotypes was $14(1.8 \%)$. Exact tests based on haplotype frequencies showed differentiation between all population pairs (all $\mathrm{p}<0.0005)$.

Population structure and genetic diversity varied, depending on the molecular marker analyzed. The microsatellite data showed a low population structure and moderate to high genetic diversity, whereas the mtDNA data showed a high population structure and low diversity in three populations. The mtDNA data suggested an absence of female gene flow among the populations, and reinforced the philopatric behavior of queens and its strong
Table 2 - Frequency and distribution of mtDNA haplotypes identified in Plebeia remota.

\begin{tabular}{lcccc}
\hline Haplotype & $\begin{array}{c}\text { Cunha } \\
(13)\end{array}$ & $\begin{array}{c}\text { Curitiba } \\
(6)\end{array}$ & $\begin{array}{c}\text { Prudentópolis } \\
(34)\end{array}$ & $\begin{array}{c}\text { Blumenau } \\
(12)\end{array}$ \\
\hline $\mathrm{h} 01$ & - & 1 & - & - \\
$\mathrm{h} 02$ & - & 1 & - & - \\
$\mathrm{h} 03$ & - & 2 & - & - \\
$\mathrm{h} 04$ & 13 & 1 & - & - \\
$\mathrm{h} 05$ & - & 1 & - & - \\
$\mathrm{h} 06$ & - & - & 23 & - \\
$\mathrm{h} 07$ & - & - & 1 & - \\
$\mathrm{h} 08$ & - & - & 8 & - \\
$\mathrm{h} 09$ & - & - & 2 & - \\
$\mathrm{h} 10$ & - & - & - & 12 \\
$\mathrm{NH}$ & 1 & 5 & 4 & 1 \\
$h$ & 0.00 & 0.93 & 0.50 & 0.00 \\
$\pi$ & 0.00000 & 0.00420 & 0.00068 & 0.00000 \\
\hline
\end{tabular}

The number of individuals analyzed is indicated in parentheses. NH: number of haplotypes; $h$ : haplotype diversity; $\pi$ : nucleotide diversity.

influence on the genetic differentiation observed. These findings agree with previous data obtained by RFPL of mtDNA that also showed no gene flow through females (Francisco and Arias, 2010).

The level of intrapopulation nuclear diversity was moderate to high. The Prudentópolis population had the lowest genetic diversity index, which suggested genetic isolation. The nuclear data also indicated a low population structure among the Cunha, Curitiba, and Blumenau populations. An absent or low genetic structure can be attributed to homoplasy in microsatellite size but should be accompanied by a decrease in genetic variability (Estoup et al., 2002), which was not the case here.

Since female philopatry was detected in these populations, the absence of genetic structure can be explained by male dispersal. The few genetic studies of Meliponini male congregations have demonstrated the presence of males from distant areas, with more than 100 colonies acting as male donors (Paxton, 2000; Cameron et al., 2004; Kraus et al., 2008; Mueller et al., 2012).

Table 1 - Genetic diversity for each population of Plebeia remota based on microsatellite data

\begin{tabular}{lcccccc}
\hline Population & $\mathrm{N}$ & $A$ & $A r$ & $H_{O}$ & $H_{E}$ & PPL \\
\hline Cunha & 13 & $7.667 \pm 0.866)$ & $5.731( \pm 0.447)$ & $0.749( \pm 0.044)$ & $0.772( \pm 0.029)$ & $100.00 \%$ \\
Curitiba & 6 & $5.933( \pm 0.679)$ & $5.933( \pm 0.679)$ & $0.644( \pm 0.067)$ & $0.692( \pm 0.049)$ & $100.00 \%$ \\
Prudentópolis & 34 & $6.600( \pm 1.041)$ & $4.110( \pm 0.522)$ & $0.551( \pm 0.078)$ & $0.582( \pm 0.076)$ & $93.33 \%$ \\
Blumenau & 12 & $6.400( \pm 0.920)$ & $4.799( \pm 0.629)$ & $0.600( \pm 0.090)$ & $0.605( \pm 0.082)$ & $86.67 \%$ \\
Mean & $16.3( \pm 1.4)$ & $6.650( \pm 0.439)$ & $5.143( \pm 0.297)$ & $0.636( \pm 0.036)$ & $0.663( \pm 0.032)$ & $95.00 \%( \pm 3.19 \%)$ \\
\hline
\end{tabular}

$A$ : allelic richness; $A r$ : allelic richness after rarefaction for six individuals; $H_{O}$ and $H_{E}$ : observed and expected heterozygosity from Hardy-Weinberg proportions, respectively; N: sample size; PPL: percentage of polymorphic loci. Values in parentheses are standard errors. 


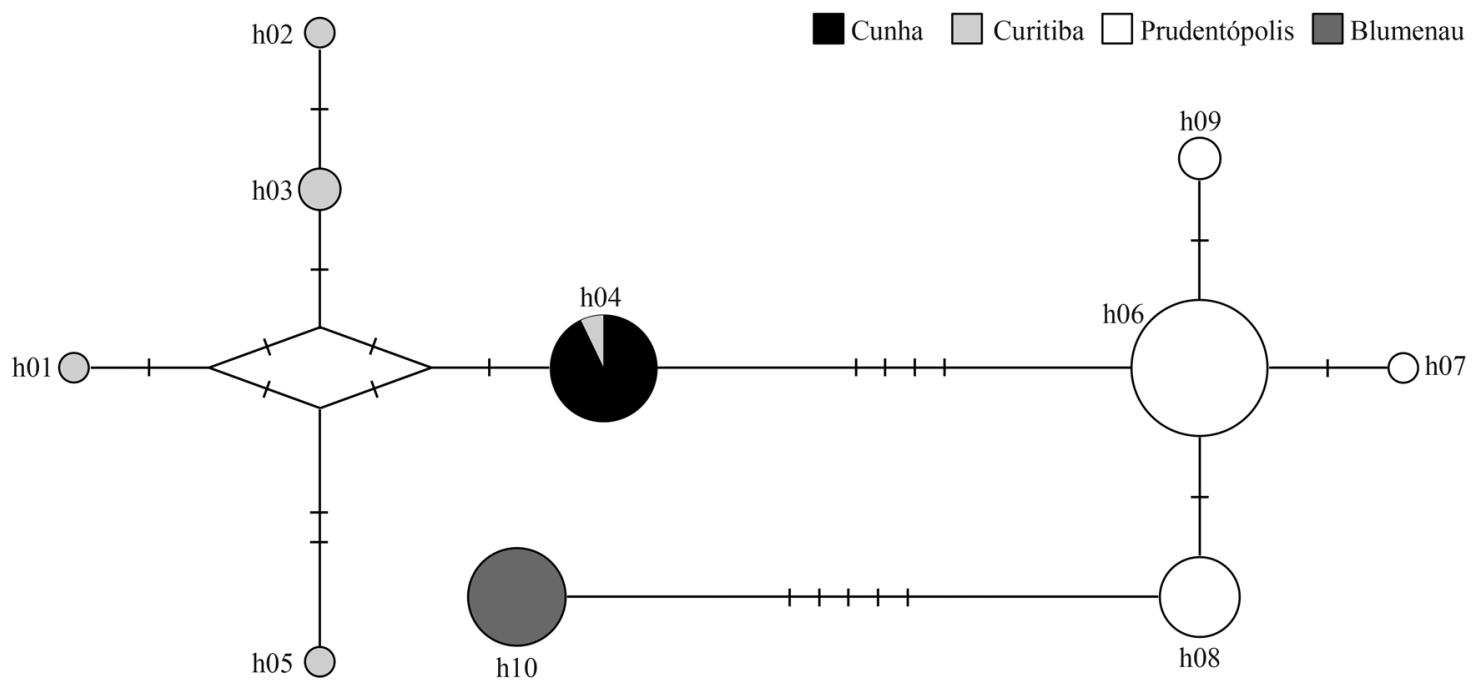

Figure 2 - mtDNA haplotype network for Plebeia remota.

Thus, the divergence between mitochondrial and nuclear data is a consequence of the reproductive behavior of $P$. remota. The low mtDNA variability indicates a low dispersal capability of females, i.e., queen philopatry. In contrast, the high nuclear genetic variability is maintained by male dispersal. This male behavior is crucial to avoid inbreeding and to keep the population genetically healthy. Since Meliponini species show queen philopatry (Nogueira-Neto, 1954; Engels and Imperatriz-Fonseca, 1990), we expect a similar genetic scenario in other species.

\section{Acknowledgments}

We thank Susy Coelho and Ana Carolina Lima Novelli for technical assistance and anonymous reviewers for their comments and suggestions on an earlier version of this manuscript. FOF was supported by scholarships (99/11190-6 and 08/08546-4) and grants (04/15801-0 and 10/50597-5) from Fundação de Amparo à Pesquisa do Estado de São Paulo (FAPESP). LRS was supported by a scholarship from Coordenação de Aperfeiçoamento de Pessoal de Nível Superior (CAPES). This work was developed in the Research Center on Biodiversity and Computing (BioComp) of the Universidade de São Paulo (USP), supported by the USP Provost's Office for Research.

\section{References}

Apio A, Kabasa JD, Ketmaier V, Schröder C, Plath M and Tiedemann R (2010) Female philopatry and male dispersal in a cryptic, bush-dwelling antelope: A combined molecular and behavioural approach. J Zool 280:213-220.

Arias MC, Brito RM, Francisco FO, Moretto G, Oliveira FF and Silvestre D (2006) Molecular markers as a tool for population and evolutionary studies of stingless bees. Apidologie 37:259-274.

Arias MC, Silvestre D, Francisco FO, Weinlich R and Sheppard WS (2008) An oligonucleotide primer set for PCR amplifi- cation of the complete honey bee mitochondrial genome. Apidologie 39:475-480.

Borges AA, Campos LAO, Salomão TMF and Tavares MG (2010) Genetic variability in five populations of Partamona helleri (Hymenoptera, Apidae) from Minas Gerais State, Brazil. Genet Mol Biol 33:781-784.

Brito RM and Arias MC (2010) Genetic structure of Partamona helleri (Apidae, Meliponini) from Neotropical Atlantic rainforest. Insectes Soc 57:413-419.

Brown MJF and Paxton RJ (2009) The conservation of bees: A global perspective. Apidologie 40:410-416.

Cameron EC, Franck P and Oldroyd BP (2004) Genetic structure of nest aggregations and drone congregations of the southeast Asian stingless bee Trigona collina. Mol Ecol 13:2357-2364.

Carvalho-Zilse GA and Kerr WE (2004) Substituição natural de rainhas fisogástricas e distância de vôo dos machos em Tiuba (Melipona compressipes fasciculata Smith, 1854) e Uruçu (Melipona scutellaris Latreille, 1811) (Apidae, Meliponini). Acta Amaz 34:649-652.

Carvalho-Zilse GA, Costa-Pinto MFF, Nunes-Silva CG and Kerr WE (2009) Does beekeeping reduce genetic variability in Melipona scutellaris (Apidae, Meliponini)? Genet Mol Res 8:758-765.

Costa RG, Tavares MG, Dias LAS and Campos LAO (2005) Isoenzyme variation in Melipona rufiventris (Hymenoptera, Apidae, Meliponina) in Minas Gerais State, Brazil. Biochem Genet 43:49-58.

Crawford NG (2010) SMOGD: Software for the measurement of genetic diversity. Mol Ecol Resour 10:556-557.

Earl DA and VonHoldt BM (2012) STRUCTURE HARVESTER: A website and program for visualizing STRUCTURE output and implementing the Evanno method. Conserv Genet Resour 4:359-361.

Edgar RC (2004) MUSCLE: Multiple sequence alignment with high accuracy and high throughput. Nucleic Acids Res 32:1792-1797.

Engels W and Imperatriz-Fonseca VL (1990) Caste development, reproductive strategies and control of fertility in honeybees and stingless bees. In: Engels W (ed) Social Insects: An Evo- 
lutionary Approach to Castes and Reproduction. Springer, Berlin, pp 166-230.

Estoup A, Jarne P and Cornuet J-M (2002) Homoplasy and mutation model at microsatellite loci and their consequences for population genetics analysis. Mol Ecol 11:1591-1604.

Evanno G, Regnaut S and Goudet J (2005) Detecting the number of clusters of individuals using the software structure: A simulation study. Mol Ecol 14:2611-2620.

Excoffier L and Lischer HE (2010) Arlequin suite ver 3.5: A new series of programs to perform population genetics analyses under Linux and Windows. Mol Ecol Resour 10:564-567.

Foley JA, DeFries R, Asner GP, Barford C, Bonan G, Carpenter SR, Chapin FS, Coe MT, Daily GC, Gibbs HK, et al. (2005) Global consequences of land use. Science 309:570-574.

Francisco FO and Arias MC (2010) Inferences of evolutionary and ecological events that influenced the population structure of \pm , a stingless bee from Brazil. Apidologie 41:216-224.

Francisco FO, Brito RM and Arias MC (2006) Allele number and heterozygosity for microsatellite loci in different stingless bee species (Hymenoptera, Apidae, Meliponini). Neotrop Entomol 35:638-643.

Francisco FO, Brito RM, Santiago LR, Gonçalves PHP, Pioker FC, Domingues-Yamada AMT and Arias MC (2011) Isolation and characterization of 15 microsatellite loci in the stingless bee Plebeia remota (Apidae, Meliponini). Conserv Genet Resour 3:417-419.

Frankham R, Ballou JD and Briscoe DA (2004) A Primer of Conservation Genetics. Cambridge University Press, New York, $236 \mathrm{pp}$.

Hilário SD, Ribeiro MF and Imperatriz-Fonseca VL (2007) Efeito do vento sobre a atividade de vôo de Plebeia remota (Holmberg, 1903) (Apidae, Meliponini). Biota Neotrop 7:225-232.

Jakobsson M and Rosenberg NA (2007) CLUMPP: A cluster matching and permutation program for dealing with label switching and multimodality in analysis of population structure. Bioinformatics 23:1801-1806.

Jost L (2008) $G_{\mathrm{ST}}$ and its relatives do not measure differentiation. Mol Ecol 17:4015-4026.

Kalinowski ST (2005) HP-Rare 1.0: A computer program for performing rarefaction on measures of allelic richness. Mol Ecol Notes 5:187-189.

Kappeler PM, Wimmer B, Zinner D and Tautz D (2002) The hidden matrilineal structure of a solitary lemur: Implications for primate social evolution. Proc R Soc B - Biol Sci 269:17551763.

Kerr WE, Carvalho GA and Nascimento VA (1996) Abelha Uruçu: Biologia, Manejo e Conservação. Fundação Acangaú, Belo Horizonte, 144 pp.

Kraus FB, Weinhold S and Moritz RFA (2008) Genetic structure of drone congregations of the stingless bee Scaptotrigona mexicana. Insectes Soc 55:22-27.

Librado P and Rozas J (2009) DnaSP v5: A software for comprehensive analysis of DNA polymorphism data. Bioinformatics 25:1451-1452.

Moritz C (2002) Strategies to protect biological diversity and the evolutionary processes that sustain it. Syst Biol 51:238-254.

Mueller MY, Moritz RF and Kraus FB (2012) Outbreeding and lack of temporal genetic structure in a drone congregation of the neotropical stingless bee Scaptotrigona mexicana. Ecol Evol 2:1304-1311.
Nogueira-Neto P (1954) Notas bionômicas sobre meliponíneos: III - Sobre a enxameagem. Arq Mus Nac 42:419-451.

Nogueira-Neto P (1997) Vida e Criação de Abelhas Indígenas Sem Ferrão. Nogueirapis, São Paulo, 445 pp.

Nyakaana S and Arctander P (1999) Population genetic structure of the African elephant in Uganda based on variation at mitochondrial and nuclear loci: Evidence for male-biased gene flow. Mol Ecol 8:1105-1115.

Paxton RJ (2000) Genetic structure of colonies and a male aggregation in the stingless bee Scaptotrigona postica, as revealed by microsatellite analysis. Insectes Soc 47:63-69.

Peakall ROD and Smouse PE (2006) Genalex 6: Genetic analysis in Excel. Population genetic software for teaching and research. Mol Ecol Notes 6:288-295.

Pritchard JK, Stephens M and Donnelly P (2000) Inference of population structure using multilocus genotype data. Genetics 155:945-959.

Rice WR (1989) Analyzing tables of statistical tests. Evolution 43:223-225.

Rosenberg NA (2004) Distruct: A program for the graphical display of population structure. Mol Ecol Notes 4:137-138.

Rousset F (2008) Genepop'007: A complete re-implementation of the genepop software for Windows and Linux. Mol Ecol Resour 8:103-106.

Simon C, Frati F, Beckenbach A, Crespi B, Liu H and Flook P (1994) Evolution, weighting, and phylogenetic utility of mitochondrial gene-sequences and a compilation of conserved polymerase chain-reaction primers. Ann Entomol Soc Am 87:651-701.

Tavares MG, Dias LAS, Borges AA, Lopes DM, Busse AHP, Costa RG, Salomão TMF and Campos LAO (2007) Genetic divergence between populations of the stingless bee uruçu amarela (Melipona rufiventris group, Hymenoptera, Meliponini): Is there a new Melipona species in the Brazilian state of Minas Gerais? Genet Mol Biol 30:667-675.

van Benthem FDJ, Imperatriz-Fonseca VL and Velthuis HHW (1995) Biology of the stingless bee Plebeia remota (Holmberg): Observations and evolutionary implications. Insectes Soc 42:71-87.

Walsh PS, Metzger DA and Higuchi R (1991) Chelex 100 as a medium for simple extraction of DNA for PCR-based typing from forensic material. BioTechniques 10:506-513.

Whitehead H (1998) Cultural selection and genetic diversity in matrilineal whales. Science 282:1708-1711.

\section{Internet Resources}

Arlequin ver. 3.5.1.3 software, http://cmpg.unibe.ch/software/arlequin35/ (June 15th, 2012).

Camargo JMF and Pedro SRM (2012) Meliponini Lepeletier, 1836. In: Moure JS, Urban D and Melo GAR (eds) Catalogue of Bees (Hymenoptera, Apoidea) in the Neotropical Region - online version. http://www.moure.cria.org.br/catalogue (October 16th, 2012).

CLUMPP ver. 1.1.2 software, http://www.stanford.edu/group/rosenberglab/clumpp.html/ (June 15th, 2012).

Distruct ver. 1.1 software, http://www.stanford.edu/group/rosenberglab/distruct.html/ (June 15th, 2012). 
DnaSP ver. 5.10.01 software, http://www.ub.edu/dnasp/ (June 15th, 2012).

Drummond AJ, Ashton B, Buxton S, Cheung M, Cooper A, Duran C, Field M, Heled J, Kearse M, Markowitz S, et al. (2010) Geneious ver 5.1. http://www.geneious.com/(June 15th, 2012).

GenAlEx ver. 6.41 software, http://www.anu.edu.au/BoZo/GenAlEx/ (June 15th, 2012).

GENEPOP ver. 4.1 .4 software, http://genepop.curtin.edu.au/ (June 15th, 2012).

HP-Rare ver. 1.0 software, http://www.montana.edu/kalinowski/Software/HPRare.htm/ (June 15th, 2012).

National Center for Biotechnology Information - GenBank, http://www.ncbi.nlm.nih.gov/genbank/ (June 15th, 2012).

Network ver. 4.6.1.0. software, http://www.fluxus-engineering.com (June 15th, 2012).

SMOGD ver. 1.2.5 software, http://www.ngcrawford.com/django/jost/ (October 16th, 2012).
Structure ver. 2.3.3 software, http://pritch.bsd.uchicago.edu/structure.html/ (June 15th, 2012).

Structure Harvester ver. 0.6.92 Software, http://taylor0.biology.ucla.edu/structureHarvester/ (June 15th, 2012).

\section{Supplementary Material}

The following online material is available for this article:

Table S1 - Allele size and frequency for each locus scored in four populations of Plebeia remota.

Table S2 $-D_{\text {est }}$ values for each population pair of Plebeia remota.

This material is available as part of the online article from http://www.scielo.br/gmb.

Associate Editor: Klaus Hartfelder

License information: This is an open-access article distributed under the terms of the Creative Commons Attribution License, which permits unrestricted use, distribution, and reproduction in any medium, provided the original work is properly cited. 
Table S1 - Allele size and frequency for each locus scored in four populations of Plebeia remota.

\begin{tabular}{|c|c|c|c|c|c|}
\hline Locus & Allele & Cunha & Curitiba & Prudentópolis & Blumenau \\
\hline \multirow[t]{5}{*}{ Prem03 } & 107 & 0.154 & 0.000 & 0.000 & 0.000 \\
\hline & 115 & 0.192 & 0.000 & 0.000 & 0.000 \\
\hline & 117 & 0.077 & 0.000 & 0.000 & 0.000 \\
\hline & 119 & 0.385 & 0.833 & 0.632 & 1.000 \\
\hline & 121 & 0.192 & 0.167 & 0.368 & 0.000 \\
\hline \multirow[t]{28}{*}{ Prem07 } & 330 & 0.038 & 0.000 & 0.000 & 0.000 \\
\hline & 332 & 0.077 & 0.000 & 0.000 & 0.000 \\
\hline & 334 & 0.115 & 0.000 & 0.000 & 0.000 \\
\hline & 336 & 0.038 & 0.000 & 0.000 & 0.042 \\
\hline & 338 & 0.038 & 0.083 & 0.000 & 0.000 \\
\hline & 340 & 0.154 & 0.000 & 0.000 & 0.000 \\
\hline & 344 & 0.115 & 0.083 & 0.000 & 0.000 \\
\hline & 346 & 0.077 & 0.000 & 0.015 & 0.167 \\
\hline & 348 & 0.000 & 0.000 & 0.059 & 0.000 \\
\hline & 350 & 0.000 & 0.000 & 0.103 & 0.000 \\
\hline & 352 & 0.038 & 0.000 & 0.000 & 0.042 \\
\hline & 354 & 0.038 & 0.167 & 0.015 & 0.083 \\
\hline & 356 & 0.000 & 0.000 & 0.029 & 0.208 \\
\hline & 358 & 0.038 & 0.000 & 0.000 & 0.125 \\
\hline & 359 & 0.038 & 0.083 & 0.162 & 0.083 \\
\hline & 360 & 0.000 & 0.000 & 0.015 & 0.000 \\
\hline & 361 & 0.038 & 0.000 & 0.074 & 0.042 \\
\hline & 362 & 0.077 & 0.083 & 0.044 & 0.042 \\
\hline & 364 & 0.038 & 0.000 & 0.221 & 0.000 \\
\hline & 366 & 0.000 & 0.083 & 0.132 & 0.000 \\
\hline & 368 & 0.000 & 0.083 & 0.132 & 0.000 \\
\hline & 370 & 0.000 & 0.000 & 0.000 & 0.083 \\
\hline & 372 & 0.000 & 0.083 & 0.000 & 0.000 \\
\hline & 374 & 0.000 & 0.083 & 0.000 & 0.000 \\
\hline & 376 & 0.000 & 0.083 & 0.000 & 0.000 \\
\hline & 378 & 0.000 & 0.083 & 0.000 & 0.042 \\
\hline & 380 & 0.038 & 0.000 & 0.000 & 0.000 \\
\hline & 393 & 0.000 & 0.000 & 0.000 & 0.042 \\
\hline \multirow[t]{8}{*}{ Prem57 } & 152 & 0.038 & 0.000 & 0.191 & 0.042 \\
\hline & 154 & 0.192 & 0.000 & 0.000 & 0.000 \\
\hline & 156 & 0.000 & 0.083 & 0.044 & 0.042 \\
\hline & 162 & 0.077 & 0.000 & 0.000 & 0.000 \\
\hline & 164 & 0.077 & 0.000 & 0.000 & 0.000 \\
\hline & 166 & 0.000 & 0.000 & 0.015 & 0.042 \\
\hline & 168 & 0.000 & 0.250 & 0.015 & 0.042 \\
\hline & 170 & 0.077 & 0.000 & 0.000 & 0.000 \\
\hline
\end{tabular}




\begin{tabular}{|c|c|c|c|c|c|}
\hline & 172 & 0.038 & 0.167 & 0.000 & 0.000 \\
\hline & 174 & 0.077 & 0.083 & 0.074 & 0.083 \\
\hline & 176 & 0.115 & 0.000 & 0.176 & 0.083 \\
\hline & 178 & 0.038 & 0.167 & 0.000 & 0.250 \\
\hline & 180 & 0.000 & 0.000 & 0.015 & 0.250 \\
\hline & 182 & 0.077 & 0.083 & 0.044 & 0.083 \\
\hline & 184 & 0.038 & 0.000 & 0.265 & 0.083 \\
\hline & 186 & 0.000 & 0.083 & 0.088 & 0.000 \\
\hline & 188 & 0.077 & 0.000 & 0.044 & 0.000 \\
\hline & 190 & 0.000 & 0.000 & 0.029 & 0.000 \\
\hline & 192 & 0.000 & 0.083 & 0.000 & 0.000 \\
\hline & 196 & 0.077 & 0.000 & 0.000 & 0.000 \\
\hline \multirow[t]{10}{*}{ Prem58 } & 160 & 0.000 & 0.000 & 0.029 & 0.000 \\
\hline & 162 & 0.000 & 0.083 & 0.000 & 0.542 \\
\hline & 164 & 0.000 & 0.000 & 0.000 & 0.042 \\
\hline & 166 & 0.038 & 0.000 & 0.000 & 0.000 \\
\hline & 168 & 0.154 & 0.083 & 0.059 & 0.292 \\
\hline & 170 & 0.231 & 0.500 & 0.000 & 0.042 \\
\hline & 172 & 0.269 & 0.167 & 0.118 & 0.083 \\
\hline & 174 & 0.192 & 0.083 & 0.721 & 0.000 \\
\hline & 176 & 0.115 & 0.000 & 0.059 & 0.000 \\
\hline & 178 & 0.000 & 0.083 & 0.015 & 0.000 \\
\hline \multirow[t]{7}{*}{ Prem70 } & 106 & 0.346 & 0.000 & 0.000 & 0.042 \\
\hline & 108 & 0.038 & 0.000 & 0.000 & 0.000 \\
\hline & 110 & 0.115 & 0.000 & 0.191 & 0.042 \\
\hline & 112 & 0.077 & 0.417 & 0.206 & 0.500 \\
\hline & 114 & 0.077 & 0.583 & 0.603 & 0.333 \\
\hline & 116 & 0.269 & 0.000 & 0.000 & 0.083 \\
\hline & 118 & 0.077 & 0.000 & 0.000 & 0.000 \\
\hline \multirow[t]{14}{*}{ Prem75a } & 185 & 0.000 & 0.000 & 0.000 & 0.125 \\
\hline & 187 & 0.154 & 0.000 & 0.000 & 0.000 \\
\hline & 189 & 0.115 & 0.000 & 0.000 & 0.000 \\
\hline & 191 & 0.000 & 0.167 & 0.412 & 0.000 \\
\hline & 193 & 0.269 & 0.083 & 0.000 & 0.042 \\
\hline & 195 & 0.231 & 0.250 & 0.176 & 0.083 \\
\hline & 197 & 0.038 & 0.167 & 0.029 & 0.167 \\
\hline & 199 & 0.000 & 0.000 & 0.044 & 0.250 \\
\hline & 201 & 0.000 & 0.000 & 0.015 & 0.083 \\
\hline & 203 & 0.077 & 0.083 & 0.147 & 0.000 \\
\hline & 205 & 0.000 & 0.000 & 0.000 & 0.083 \\
\hline & 209 & 0.038 & 0.000 & 0.029 & 0.042 \\
\hline & 214 & 0.038 & 0.000 & 0.000 & 0.000 \\
\hline & 215 & 0.000 & 0.000 & 0.132 & 0.042 \\
\hline
\end{tabular}




\begin{tabular}{|c|c|c|c|c|c|}
\hline & 217 & 0.038 & 0.000 & 0.000 & 0.083 \\
\hline & 219 & 0.000 & 0.167 & 0.000 & 0.000 \\
\hline & 221 & 0.000 & 0.083 & 0.000 & 0.000 \\
\hline & 225 & 0.000 & 0.000 & 0.015 & 0.000 \\
\hline \multirow[t]{13}{*}{ Prem78 } & 176 & 0.269 & 0.000 & 0.426 & 0.125 \\
\hline & 178 & 0.192 & 0.167 & 0.000 & 0.125 \\
\hline & 180 & 0.077 & 0.250 & 0.000 & 0.125 \\
\hline & 184 & 0.154 & 0.000 & 0.000 & 0.000 \\
\hline & 186 & 0.000 & 0.167 & 0.000 & 0.000 \\
\hline & 190 & 0.000 & 0.000 & 0.000 & 0.042 \\
\hline & 192 & 0.000 & 0.167 & 0.015 & 0.167 \\
\hline & 194 & 0.000 & 0.083 & 0.103 & 0.167 \\
\hline & 196 & 0.115 & 0.000 & 0.279 & 0.083 \\
\hline & 198 & 0.000 & 0.000 & 0.059 & 0.083 \\
\hline & 200 & 0.192 & 0.000 & 0.118 & 0.000 \\
\hline & 202 & 0.000 & 0.083 & 0.000 & 0.083 \\
\hline & 207 & 0.000 & 0.083 & 0.000 & 0.000 \\
\hline \multirow[t]{5}{*}{ Prem79 } & 209 & 0.000 & 0.000 & 0.000 & 0.042 \\
\hline & 216 & 0.231 & 0.750 & 1.000 & 0.958 \\
\hline & 218 & 0.269 & 0.083 & 0.000 & 0.000 \\
\hline & 220 & 0.308 & 0.083 & 0.000 & 0.000 \\
\hline & 222 & 0.192 & 0.083 & 0.000 & 0.000 \\
\hline \multirow[t]{13}{*}{ Prem81a } & 123 & 0.038 & 0.000 & 0.059 & 0.000 \\
\hline & 127 & 0.000 & 0.000 & 0.147 & 0.000 \\
\hline & 129 & 0.038 & 0.000 & 0.088 & 0.500 \\
\hline & 131 & 0.038 & 0.000 & 0.029 & 0.208 \\
\hline & 133 & 0.077 & 0.167 & 0.103 & 0.125 \\
\hline & 135 & 0.000 & 0.250 & 0.235 & 0.000 \\
\hline & 137 & 0.154 & 0.083 & 0.044 & 0.000 \\
\hline & 139 & 0.346 & 0.333 & 0.000 & 0.000 \\
\hline & 141 & 0.038 & 0.000 & 0.015 & 0.000 \\
\hline & 143 & 0.269 & 0.167 & 0.132 & 0.000 \\
\hline & 145 & 0.000 & 0.000 & 0.088 & 0.125 \\
\hline & 147 & 0.000 & 0.000 & 0.044 & 0.042 \\
\hline & 151 & 0.000 & 0.000 & 0.015 & 0.000 \\
\hline \multirow[t]{7}{*}{ Prem82 } & 145 & 0.115 & 0.417 & 0.162 & 0.083 \\
\hline & 149 & 0.115 & 0.083 & 0.000 & 0.000 \\
\hline & 150 & 0.000 & 0.000 & 0.162 & 0.000 \\
\hline & 151 & 0.077 & 0.083 & 0.000 & 0.042 \\
\hline & 153 & 0.385 & 0.083 & 0.044 & 0.292 \\
\hline & 154 & 0.077 & 0.167 & 0.059 & 0.583 \\
\hline & 155 & 0.115 & 0.083 & 0.529 & 0.000 \\
\hline
\end{tabular}




\begin{tabular}{|c|c|c|c|c|c|}
\hline & 157 & 0.115 & 0.083 & 0.044 & 0.000 \\
\hline \multirow[t]{14}{*}{ Prem83 } & 208 & 0.000 & 0.000 & 0.015 & 0.083 \\
\hline & 217 & 0.000 & 0.083 & 0.000 & 0.000 \\
\hline & 221 & 0.115 & 0.000 & 0.015 & 0.000 \\
\hline & 223 & 0.038 & 0.000 & 0.000 & 0.125 \\
\hline & 225 & 0.231 & 0.000 & 0.044 & 0.042 \\
\hline & 227 & 0.038 & 0.000 & 0.147 & 0.042 \\
\hline & 229 & 0.038 & 0.417 & 0.147 & 0.083 \\
\hline & 231 & 0.077 & 0.167 & 0.324 & 0.208 \\
\hline & 233 & 0.115 & 0.250 & 0.074 & 0.167 \\
\hline & 235 & 0.077 & 0.083 & 0.044 & 0.042 \\
\hline & 237 & 0.192 & 0.000 & 0.015 & 0.042 \\
\hline & 239 & 0.077 & 0.000 & 0.044 & 0.125 \\
\hline & 241 & 0.000 & 0.000 & 0.103 & 0.042 \\
\hline & 243 & 0.000 & 0.000 & 0.029 & 0.000 \\
\hline \multirow[t]{11}{*}{ Prem84 } & 166 & 0.308 & 0.083 & 0.000 & 0.167 \\
\hline & 168 & 0.231 & 0.583 & 0.441 & 0.292 \\
\hline & 170 & 0.192 & 0.000 & 0.235 & 0.292 \\
\hline & 172 & 0.000 & 0.083 & 0.000 & 0.042 \\
\hline & 174 & 0.000 & 0.167 & 0.000 & 0.000 \\
\hline & 176 & 0.038 & 0.083 & 0.000 & 0.083 \\
\hline & 178 & 0.000 & 0.000 & 0.029 & 0.000 \\
\hline & 180 & 0.038 & 0.000 & 0.191 & 0.125 \\
\hline & 182 & 0.077 & 0.000 & 0.000 & 0.000 \\
\hline & 186 & 0.077 & 0.000 & 0.000 & 0.000 \\
\hline & 188 & 0.038 & 0.000 & 0.103 & 0.000 \\
\hline \multirow[t]{16}{*}{ Prem87 } & 126 & 0.038 & 0.000 & 0.000 & 0.000 \\
\hline & 128 & 0.000 & 0.000 & 0.162 & 0.000 \\
\hline & 130 & 0.077 & 0.000 & 0.235 & 0.000 \\
\hline & 132 & 0.577 & 0.167 & 0.015 & 0.000 \\
\hline & 134 & 0.115 & 0.250 & 0.147 & 0.000 \\
\hline & 136 & 0.077 & 0.167 & 0.294 & 0.083 \\
\hline & 138 & 0.038 & 0.083 & 0.103 & 0.458 \\
\hline & 140 & 0.000 & 0.000 & 0.000 & 0.125 \\
\hline & 142 & 0.000 & 0.167 & 0.015 & 0.125 \\
\hline & 144 & 0.000 & 0.000 & 0.000 & 0.042 \\
\hline & 146 & 0.000 & 0.000 & 0.000 & 0.125 \\
\hline & 154 & 0.077 & 0.000 & 0.000 & 0.000 \\
\hline & 156 & 0.000 & 0.000 & 0.029 & 0.000 \\
\hline & 162 & 0.000 & 0.083 & 0.000 & 0.000 \\
\hline & 164 & 0.000 & 0.000 & 0.000 & 0.042 \\
\hline & 176 & 0.000 & 0.083 & 0.000 & 0.000 \\
\hline
\end{tabular}




\begin{tabular}{|l|l|l|l|l|l|}
\hline Prem93 & 106 & 0.692 & 0.167 & 0.000 & 0.000 \\
\hline & 108 & 0.269 & 0.667 & 0.912 & 0.000 \\
\hline & 110 & 0.038 & 0.167 & 0.088 & 1.000 \\
\hline & & & & & \\
\hline Prem94 & 189 & 0.269 & 0.167 & 0.971 & 0.542 \\
\hline & 191 & 0.038 & 0.083 & 0.015 & 0.125 \\
\hline & 193 & 0.346 & 0.083 & 0.000 & 0.000 \\
\hline & 195 & 0.115 & 0.000 & 0.000 & 0.000 \\
\hline & 197 & 0.115 & 0.000 & 0.000 & 0.000 \\
\hline & 199 & 0.115 & 0.000 & 0.015 & 0.125 \\
\hline & 201 & 0.000 & 0.083 & 0.000 & 0.042 \\
\hline & 207 & 0.000 & 0.167 & 0.000 & 0.042 \\
\hline & 210 & 0.000 & 0.000 & 0.000 & 0.042 \\
\hline & 214 & 0.000 & 0.000 & 0.000 & 0.042 \\
\hline & 216 & 0.000 & 0.000 & 0.000 & 0.042 \\
\hline & 220 & 0.000 & 0.083 & 0.000 & 0.000 \\
\hline & 222 & 0.000 & 0.083 & 0.000 & 0.000 \\
\hline & 224 & 0.000 & 0.083 & 0.000 & 0.000 \\
\hline & 225 & 0.000 & 0.083 & 0.000 & 0.000 \\
\hline & 226 & 0.000 & 0.083 & 0.000 & 0.000 \\
\hline
\end{tabular}


Table S2 - $D_{\text {est }}$ values for each population pair of Plebeia remota.

\begin{tabular}{lcccc}
\cline { 2 - 5 } & Cunha & Curitiba & Prudentópolis & Blumenau \\
\hline Cunha & 0.00 & & & \\
Curitiba & 0.25 & 0.00 & & \\
Prudentópolis & 0.49 & 0.21 & 0.00 & \\
Blumenau & 0.43 & 0.20 & 0.32 & 0.00 \\
\hline
\end{tabular}

